\title{
Zinc Finger Protein 429
}

National Cancer Institute

\section{Source}

National Cancer Institute. Zinc Finger Protein 429. NCI Thesaurus. Code C143102.

Zinc finger protein 429 (674 aa, $78 \mathrm{kDa}$ ) is encoded by the human ZNF429 gene. This protein may play a role in the regulation of transcription. 